AperTO - Archivio Istituzionale Open Access dell'Università di Torino

\title{
LIC-KOR-Promoted Synthesis of Alkoxydienyl Amines: An Entry to 2,3,4,5-Tetrasubstituted Pyrroles
}

\section{This is the author's manuscript}

Original Citation:

Availability:

This version is available http://hdl.handle.net/2318/61988

since

Published version:

DOI:10.1021/ol9015018

Terms of use:

Open Access

Anyone can freely access the full text of works made available as "Open Access". Works made available under a Creative Commons license can be used according to the terms and conditions of said license. Use of all other works requires consent of the right holder (author or publisher) if not exempted from copyright protection by the applicable law. 


\section{LIC-KOR-Promoted Synthesis of Alkoxydienyl Amines: An Entry to 2,3,4,5-Tetrasubstituted Pyrroles}

\section{Marco Blangetti, ${ }^{\dagger}$ Annamaria Deagostino, Cristina Prandi, ${ }^{*}$ Silvia Tabasso, and Paolo Venturello}

Dipartimento di Chimica Generale e Chimica Organica, Università di Torino,

Via P. Giuria 7, 10125 Torino, Italy

cristina.prandi@unito.it

Received July 1, 2009

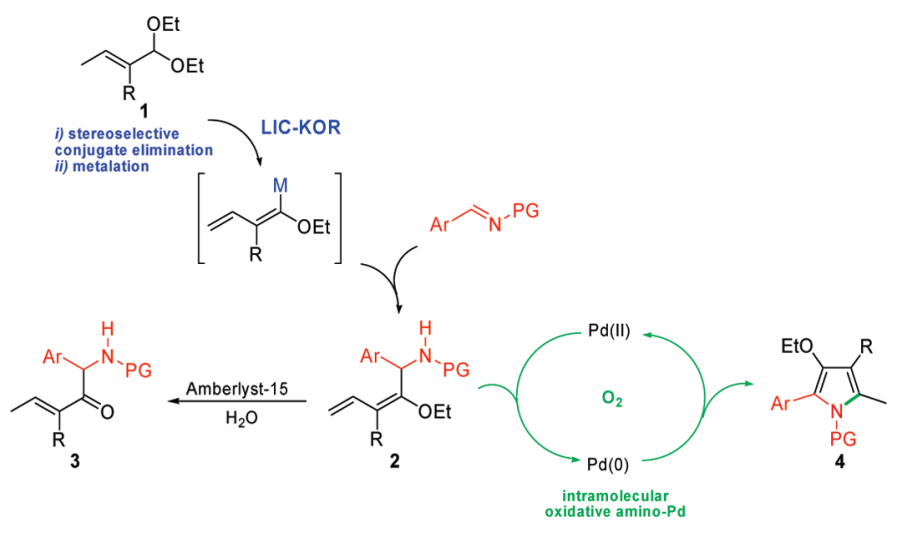

A stereoselective approach to the synthesis of $(E)$-alkoxydienylamines (2) is described, starting from $\alpha, \beta$-unsaturated acetals (1) and aryl imines, under superbasic conditions. These can be readily converted into $\alpha$-arylglycine derivatives (3) by mild acidic hydrolysis or, in turn, cyclized under oxidative conditions in the presence of a Pd catalyst to 2,3,4,5-tetrasubstituted pyrroles (4).

Compounds containing nitrogen-heterocyclic frameworks are widespread in many naturally occurring molecules and find applications both in medicine and agriculture. ${ }^{1}$ Pyrroles deserve particular attention in this group as they play crucial roles. Importantly, the construction of multiple substituted pyrrole rings typically relies on classical approaches such as the Knorr, Hantzsch, and Paal-Knorr

\footnotetext{
${ }^{\dagger}$ Partially taken from the Ph.D. thesis of M.B.

(1) For reviews, see: (a) Eicher, T.; Hauptmann, S. The Chemistry of Heterocycles-Structure, Reactions, Synthesis and Application; (translated by Suschitzky, H.; Suschitzky, J.); VCH: Weinheim, 2003. (b) Gribble, G. W. In Comprehensive Heterocyclic Chemistry; Katritzky, A. R., Rees, C. W., Scriven, E. F. V., Eds.; Pergamon: Oxford 1996; Vol. 2, p 207. (c) Joule, J. A.; Millis, K. In Heterocyclic Chemistry: Blackwell Science: Oxford, UK 2000. (d) Jones, R. A. The Chemistry of Heterocyclic Compounds: Pyrroles; Wiley: New York, 1990; Vol. 48. (e) Black, D. S. In Science of Synthesis; Maas, G., Ed.; Thieme: Stuttgart, 2001; Vol. 5, p 441.

condensations. ${ }^{2}$ Many alternative strategies respectively based on cyclization, ${ }^{3}$ multicomponent, ${ }^{4}$ aza-Nazarov cyclization, ${ }^{5}$ or transition-metal-catalyzed reactions have been proposed. Tetrasubstituted pyrroles have recently been prepared starting from propargylic vinyl ethers and aromatic $^{\text {amines }^{6}}$ or omopropargylic azides ${ }^{7}$ in $\mathrm{Au}-$ catalyzed processes. In recent years, $\mathrm{Cu}$-promoted $\mathrm{C}-\mathrm{N}$ bond-forming reactions have drawn considerable attention. Pyrroles with different substitution patterns have been successfully synthesized starting from iodo enynes, ${ }^{8}$ bromo enones, ${ }^{9}$ and 1,4-halo-1,3-dienes. ${ }^{10}$ A powerful synthetic

(2) For recent examples, see: (a) Shiner, C. M.; Lash, T. D. Tetrahedron 2005, 61, 11628. (b) Minetto, G.; Raveglia, L. F.; Sega, A.; Taddei, M. Eur. J. Org. Chem. 2005, 5277. (c) Calvo, L.; Gonzales-Ortega, A.; Saòudo, M. C. Synthesis 2002, 2450. (d) Chen, J.; Wu, H.; Zeng, Z.; Jin, C.; Zhang, X.; Su, W. Tetrahedron Lett. 2006, 47, 5383. 
method used to construct nitrogen-containing heterocycles involves the direct amination of olefins by $\mathrm{C}-\mathrm{N}$ bond formation. Unsaturated amines have been successfully used to synthesize pyrrolidine derivatives via a Pd(II)catalyzed cyclization. ${ }^{11}$ Recently, the aminopalladation route gained a renewed interest through the introduction of new Pd catalysts and reaction conditions that turned out to be compatible with the use of dioxygen as an oxidant. Since the first nearly simultaneous publication by Hiemstra and Larock of an aerobic oxidative heterocyclization on a variety of alkenes with $\mathrm{Pd}(\mathrm{OAc})_{2} /$ DMSO, ${ }^{12}$ new catalysts and conditions have been proposed; among these are $\mathrm{N}$-heterocyclic carbene ligands ${ }^{13}$ and an asymmetric version of the process. ${ }^{14}$ Despite remarkable recent developments in this area, as far as we are aware 1,3-dienes have been rarely used as substrates. ${ }^{15}$ Due to our interest in the reactivity and exploitation of $\alpha$-metalated 1-alkoxy-1,3-dienes as building blocks in organic synthesis, ${ }^{16}$ we recently focused our attention on electrophiles containing multiple $\mathrm{C}-\mathrm{N}$ bonds. ${ }^{17}$ Herein we report the synthesis of functionalized alkoxydienyl amines and their use both as precursors of $\alpha$-aryl glycines

(3) For recent examples, see: (a) St. Cyr, D. J.; Arndtsen, B. A. J. Am. Chem. Soc. 2007, 129, 12366. (b) Larionov, O. V.; de Meijere, A. Angew. Chem., Int. Ed. 2005, 44, 5664. (c) Tejedor, D.; Gonzalez-Cruz, D.; GarciaTellado, F.; Marrero-Tellado, J. J.; Rodriguez, M. L. J. Am. Chem. Soc. 2004, 126, 8390. (d) Huang, X.; Shen, R. W.; Zhang, T. X. J. Org. Chem. 2007, 72, 1534. (e) Milgram, B. C.; Eskildsen, K.; Richter, S. M.; Scheidt, W. R.; Scheidt, K. A. J. Org. Chem. 2007, 72, 3941. (f) Martin, C.; Maddaluno, J.; Duhamel, L. Tetrahedron Lett. 1995, 36, 9469. Martin, C.; Maddaluno, J.; Duhamel, L. Tetrahedron Lett. 1996, 37, 8169. (g) Zhang, Z.; Zhang, J.; Tan, J.; Wang, Z. J. Org. Chem. 2008, 73, 5180. (h) Kamijo, S.; Kanazawa, C.; Yamamoto, Y. J. Am. Chem. Soc. 2005, 127, 9260.

(4) For recent examples, see: (a) St. Cyr, D. J.; Martin, N.; Arndtsen, B. A. Org. Lett. 2007, 9, 449. (b) Nair, V.; Vinod, A. U.; Rajesh, C. J. Org. Chem. 2001, 66, 4427.

(5) (a) Dieker, J.; Frohlich, R.; Wurthwein, E. U. Eur. J. Org. Chem. 2006, 5339. (b) Ghavtadze, N.; Frohlich, R.; Wurthwein, E. U. Eur. J. Org. Chem. 2008, 3656.

(6) Binder, J. T.; Kirsch, S. F. Org. Lett. 2006, 8, 2151.

(7) Gorin, D. J.; Davis, N. R.; Toste, F. D. J. Am. Chem. Soc. 2005, 127,11260 .

(8) Martin, R.; Rivero, M. R.; Buchwald, S. L. Angew. Chem., Int. Ed. 2006, 45, 7079 .

(9) Pan, Y. J.; Lu, H. J.; Fang, Y. W.; Fang, X. Q.; Chen, L. Q.; Qian, J. L.; Wang, J. H.; Li, C. Z. Synthesis 2007, 1242.

(10) (a) Yuan, X. Y.; Xu, X. B.; Zhou, X. B.; Yuan, J. W.; Mai, L. G.; Li, Y. Z. J. Org. Chem. 2007, 72, 1510. (b) Martin, R.; Larsen, C. H.; Cuenca, A.; Buchwald, S. L. Org. Lett. 2007, 9, 3379.

(11) (a) Rönn, M.; Bäckvall, J. E.; Andersson, P. G. Tetrahedron Lett. 1995, 36, 7749. (b) Michael, F. E.; Cochran, B. M. J. Am. Chem. Soc. 2006, 128, 4246. (c) Alexanian, E. J.; Lee, C.; Sorensen, E. J. J. Am. Chem. Soc. 2005, 127, 7690 .

(12) (a) Larock, R. C.; Hightower, T. R. J. Org. Chem. 1993, 58, 5298. (b) Larock, R. C.; Hightower, T. R.; Hasvold, L. A.; Peterson, K. P. J. Org. Chem. 1996, 61, 3584. (c) Anbenthem, R.; Hiemstra, H.; Michels, J. J.; Speckamp, W. N. J. Chem. Soc., Chem. Commun. 1994, 357. (d) Vanbenthem, R.; Hiemstra, H.; Longarela, G. R.; Speckamp, W. N. Tetrahedron Lett. 1994, 35, 9281.

(13) Carborough, C. C.; Stahl, S. S. Org. Lett. 2006, 8, 3251.

(14) Liu, G.; Stahl, S. S. J. Am. Chem. Soc. 2007, 129, 7690. For a recent example of cascade aminopalladation, see: Yip, K.-T.; Zhu, N.-Y.; Yang, D. Org. Lett. 2009, 11, 1911.

(15) (a) Bar, G. L. J.; Lloyd-Jones, G. C.; Booker-Milburn, K. I. J. Am. Chem. Soc. 2005, 127, 7308. (b) Åkermark, B.; Bäckvall, J. E.; Löwbenerg, K.; Zetterberg, K. J. Organomet. Chem. 1979, 166, C33. (c) Bäckvall, J. E.; Andersson, P. G. J. Am. Chem. Soc. 1990, 112, 3683.

(16) Deagostino, A.; Prandi, C.; Zavattaro, C.; Venturello, P. Eur. J. Org. Chem. 2006, 11, 2463, and references therein.

(17) Blangetti, M.; Deagostino, A.; Prandi, C.; Zavattaro, C.; Venturello, P. Chem. Commun. 2008, 1689. and as substrates in aminopalladation reactions to 2,3,4,5tetrasubstituted $\mathrm{N}$-tosylpyrroles.

In the course of these studies, which are aimed at the addition of the metalated alkoxydienyl moiety, we were particularly interested in investigating the reactivity of imines as electrophiles. $\mathrm{N}$-Aryl-, $\mathrm{N}$-tosyl-, and $\mathrm{N}$-Bocprotected imines were successfully prepared from the corresponding aldehydes and suitable amines, according to literature procedures. ${ }^{18}$ The metalation of $\mathbf{1 a}$ and $\mathbf{1 b}$ (Table 1) with 2 equiv of LIC-KOR base (equimolar

Table 1. Synthesis of Alkoxydienyl Amines

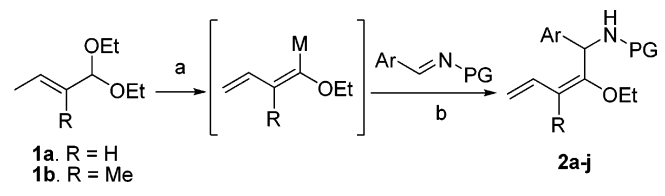

\begin{tabular}{cccllc}
\hline entry & product & $\mathrm{R}$ & $\mathrm{PG}$ & \multicolumn{1}{c}{$\mathrm{Ar}$} & yield $^{a}(\%)$ \\
\hline 1 & $\mathbf{2 a}$ & $\mathrm{H}$ & $\mathrm{Ph}$ & $\mathrm{Ph}$ & 57 \\
2 & $\mathbf{2 b}$ & $\mathrm{H}$ & $\mathrm{Ts}$ & $\mathrm{Ph}$ & 86 \\
3 & $\mathbf{2 c}$ & $\mathrm{H}$ & $\mathrm{Ts}$ & $p$-Tol & 82 \\
4 & $\mathbf{2 d}$ & $\mathrm{H}$ & $\mathrm{Ts}$ & $p$ - $\mathrm{MeOC}_{6} \mathrm{H}_{4}$ & 91 \\
5 & $\mathbf{2 e}$ & $\mathrm{H}$ & $\mathrm{Ts}$ & 2 -thienyl & 79 \\
6 & $\mathbf{2 f}$ & $\mathrm{H}$ & $\mathrm{Ts}$ & $p-\mathrm{BrC}_{6} \mathrm{H}_{4}$ & 41 \\
7 & $\mathbf{2 g}$ & $\mathrm{H}$ & $\mathrm{Boc}$ & $\mathrm{Ph}$ & 25 \\
8 & $\mathbf{2 h}$ & $\mathrm{Me}$ & $\mathrm{Ts}$ & $\mathrm{Tol}$ & 74 \\
9 & $\mathbf{2 j}$ & $\mathrm{Me}$ & $\mathrm{Ts}$ & $p-\mathrm{MeOC}_{6} \mathrm{H}_{4}$ & 63 \\
${ }^{a}$ Yields of isolated products. & &
\end{tabular}

mixture of BuLi and $t$-BuOK) $)^{19}$ afforded the $(E)-(1-$ ethoxybuta-1,3-dienyl)metal (metal $=\mathrm{Li}$ or $\mathrm{K}$ ); dienylamines 2 were then obtained upon addition of the suitable imine according to a nucleophilic addition mechanism. ${ }^{20}$ In view of further elaborations of the products, different protecting groups were employed, such as phenyl (entry 1, Table 1), tosyl (entries 2-6, 8, and 9), and Boc (entry 7). As expected, the reactivity of $N$-phenylimine was poor, due to the low reactivity of the iminic carbon; nevertheless, the corresponding dienylamine $\mathbf{2 a}$ was successfully isolated even though in moderate yield (57\%). ${ }^{21}$ Using these data as a starting point, we considered the reactivity of other electrophilic $N$-protected imines to improve yields

(18) (a) Taguchi, K.; Westheimer, F. H. J. Org. Chem. 1971, 11, 1570. (b) Ram, R. N.; Khan, A. A. Synth. Commun. 2001, 31, 841. (c) Kanazawa, A. M.; Denis, J. N.; Greene, A. E. J. Org. Chem. 1994, 59, 1238.

(19) (a) Schlosser, M. J. Organomet. Chem. 1967, 8, 9. (b) Schlosser, M. In Modern Synthetic Methods; Scheffold, R., Eds.; VCH: Weinheim, Germany, 1992; p 227. (c) Mordini, A. In Advances in Carbanion Chemistry; Snieckus, V., Ed.; JAI Press, Inc.: Greenwich, CT, 1992; Vol. 1, pp 1-45. (e) Lochmann, L. Eur. J. Inorg. Chem. 2000, 1115.

(20) For a stereoselective approach to dienylamines starting from enantiomerically enriched stannylated allylamines, see: Reginato, G.; Gaggini, F.; Mordini, A.; Valacchi, M. Tetrahedron 2005, 61, 6791.

(21) $\mathrm{N}$-Boc-dienylamine $\mathbf{2 g}$ has been recovered with an unsatisfactory yield (25\%, entry 7 , Table 1 ) along with byproducts coming from the damage of the Boc protecting group, which turns out to be unstable under superbasic conditions. $N$-Protected alkyl imines have not been considered for this work, as they enolize in the superbasic medium. 
and selectively obtain pure products. Thus, $N$-tosylaldimines were employed as electrophiles in the abovementioned reaction: when $(E)-N$-benzylidene-4-methylbenzenesulfonamide was used as an electrophile the corresponding $\mathrm{N}$-tosyldienylamine $\mathbf{2} \mathbf{b}$ was produced in $86 \%$ yield. Once the experimental conditions were set up, the synthesis was successfully carried out with $\mathrm{N}$ tosylaldimines bearing various aromatic rings (Table 1). $N$-Tosyltolyl, $p$-methoxyphenyl, and thienyl aldimines all gave good product yields (entries 3-5, 79-91\%), while $p$-bromophenyl aldimine proved to be troublesome due to possible metal-bromine exchange side reactions occurring in the superbasic medium. Furthermore, 3-methylsubstituted pentadienyl sulfonamides $\mathbf{2 h}$ and $\mathbf{2} \mathbf{j}$ (entries 8 and 9) were successfully obtained from acetal $\mathbf{1 b}$. Linear dienylamines $\mathbf{2 a}-\mathbf{f}, \mathbf{h}-\mathbf{j}$ were then treated with Amberlyst15 in $\mathrm{CH}_{2} \mathrm{Cl}_{2}$ or with aqueous $1 \mathrm{~N} \mathrm{HCl}\left(\mathrm{H}_{2} \mathrm{O} / \mathrm{THF}=1: 1\right)$. The reaction proceeds toward the hydrolysis of the vinyl ether moiety, leading to $N$-protected $\alpha$-arylglycines derivatives $\mathbf{3 a}-\mathbf{f}, \mathbf{h}-\mathbf{j}$ with good to excellent yields as depicted in Scheme $1 .^{22}$

Scheme 1. Deprotection of Alkoxydienylamines into Arylglycines<smiles>[R6]NC([Al])C(OCC)=C([R])C=C</smiles>

2a $R=H, P G=P h$

2b-f $R=H, P G=T s$

$2 h-j R=M e, P G=T s$

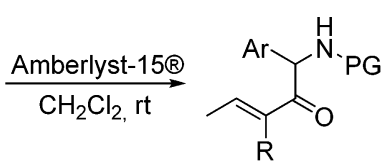

3a (97\%), 3b (90\%),

3c $(89 \%)$, 3d $(81 \%)$

3e $(76 \%)$, 3f $(89 \%)$

3h (88\%), 3j (79\%)
Besides the unmasking procedure which affords $\alpha$-aryl glycines, dienylamines were successfully used as suitable substrates for an aminopalladation process (Table 2) that

Table 2. Aminopalladation Reactions on Alkoxydienylamines

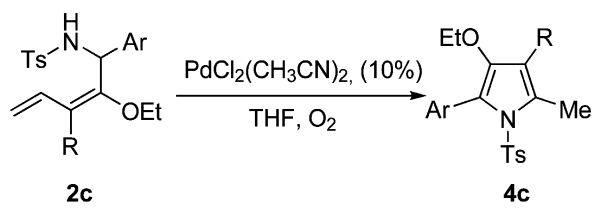

\begin{tabular}{cllccc}
\hline entry & solvent & additive/base ${ }^{a}$ & oxidant & $\begin{array}{c}T\left({ }^{\circ} \mathrm{C}\right) / \\
\text { time }(\mathrm{h})\end{array}$ & $\begin{array}{c}\text { yield }^{b} \\
(\%)\end{array}$ \\
\hline 1 & $\mathrm{THF}$ & $\mathrm{LiCl}, \mathrm{Na}_{2} \mathrm{CO}_{3}$ & $\mathrm{PBQ}$ & $50 / 5$ & 65 \\
2 & toluene & $\mathrm{LiCl}, \mathrm{Na}_{2} \mathrm{CO}_{3}$ & $\mathrm{PBQ}$ & $50 / 5$ & 10 \\
3 & toluene & $\mathrm{LiCl}, \mathrm{Na}_{2} \mathrm{CO}_{3}$ & $\mathrm{O}_{2}$ & $80 / 8$ & 25 \\
4 & THF & $\mathrm{LiCl}, \mathrm{Na}_{2} \mathrm{CO}_{3}$ & $\mathrm{O}_{2}$ & $50 / 8$ & 95 \\
$5^{c}$ & DMSO & & $\mathrm{O}_{2}$ & $70 / 6$ & 15 \\
$6^{c}$ & DMSO & $\mathrm{CH}_{3} \mathrm{CO}_{2} \mathrm{Na}$ & $\mathrm{O}_{2}$ & $70 / 9$ & 10
\end{tabular}

${ }^{a}$ The reactions were conducted in the presence of 2 equiv of base and 2 equiv of additive. ${ }^{b}$ Yields of isolated products. ${ }^{c} \mathrm{Pd}(\mathrm{OAc})_{2} \quad 10 \%$ as a catalyst was used. takes place according to a 5-exo-trig cyclization and leads to $N$-tosyl tri- or tetrasubstituted pyrroles. ${ }^{23}$ At first, when the reaction was conducted in the presence of $10 \mathrm{~mol} \%$ of $\mathrm{PdCl}_{2}\left(\mathrm{CH}_{3} \mathrm{CN}\right)_{2}$ in THF at $50{ }^{\circ} \mathrm{C}$ with benzoquinone as an oxidant, the desired pyrrole was obtained after $5 \mathrm{~h}$ in a $65 \%$ yield (entry 1 , Table 2 ). ${ }^{24}$ We were particularly interested in using reaction conditions compatible with an efficient dioxygen-coupled turnover without requiring the presence of an external oxidant (benzoquinone, $\mathrm{Cu}$ (II), or other redoxactive cocatalyst).

Thus, when the reaction was performed under an $\mathrm{O}_{2}$ atmosphere (1 atm) in THF (entry 4) a good conversion was obtained. Interestingly, in contrast with the data found in the literature, ${ }^{12}$ the use of toluene or DMSO as solvents as well as $\mathrm{Pd}(\mathrm{OAc})_{2}$ as a catalyst gave unsatisfactory results both with benzoquinone and with oxygen.

As can be deduced from the data reported in Table 2, a chloride-bearing $\mathrm{Pd}(\mathrm{II})$ catalyst, a weakly coordinating solvent, a base, and $\mathrm{LiCl}$ that is supposed to stabilize the ammonium salt intermediate are all essential for successful reactions. The results have been rationalized on the basis of the representative catalytic cycle shown in Scheme 2.

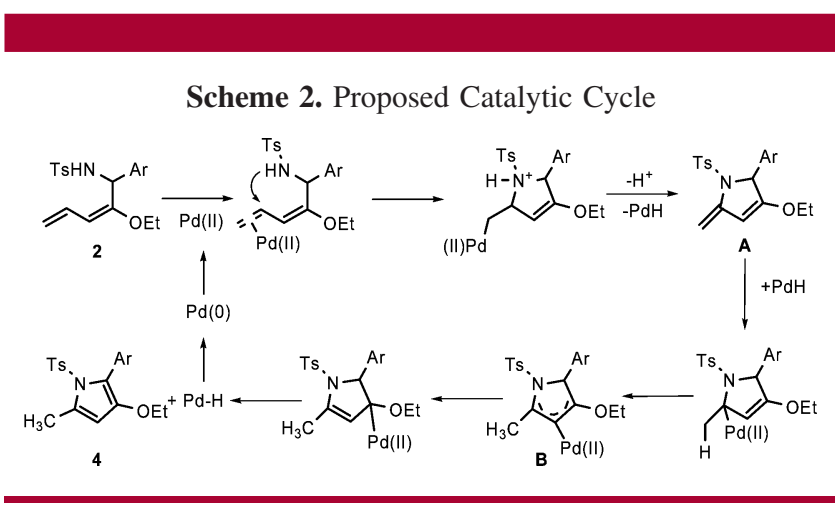

Aminopalladation of the diene, followed by $\beta$-hydride elimination, generates the heterocyclic product $\mathbf{A}$ and $\mathrm{Pd}-\mathrm{H}$. Then a hydropalladation takes place on the exocyclic double bond affording an allylic palladium complex $\mathbf{B}$ which undergoes a further $\beta$-hydride elimination to give the final pyrroles 4 .

The reduced catalyst is then directly oxidized by molecular oxygen to regenerate the $\mathrm{Pd}(\mathrm{II})$ catalyst. To extend the generality of this coupling reaction, an annulation process using various functionalized $N$-tosyl protected dienyl amines under optimized conditions was examined. The results are summarized in Table 3. Electronic effects seem to play a role as 3-ethoxy-5-methyl-2-p-tolyl-1-tosyl-1H-pyrrole $\mathbf{4 c}$

(22) Enantioselective $\alpha$-arylglycine synthesis is currently under investigation in our laboratory.

(23) We decided to consider only $N$-tosyldienylamines on the grounds that less nucleophilic nitrogen atoms are more reactive in aminopalladation reactions. For examples on this subject, see: Beccalli, E. M.; Broggini, G.; Martinelli, M.; Sottocornola, S. Chem. Rev. 2007, 107, 5318.

(24) Attempts to reduce the amount of Pd(II) by the presence of $\mathrm{Cu}(\mathrm{II})$ salts as cocatalysts led to low yield of pyrroles. 
Table 3. Synthesis of Tri- and Tetrasubstituted Pyrroles ${ }^{a}$

\begin{tabular}{|c|c|c|c|c|}
\hline entry & product & oxidant & $\begin{array}{l}T\left({ }^{\circ} \mathrm{C}\right) / \\
\text { time }(\mathrm{h})\end{array}$ & yield $^{\mathrm{a}}$ \\
\hline 1 & & $\mathrm{O}_{2}$ & $50 / 24$ & 58 \\
\hline 2 & & $\mathrm{O}_{2}$ & $50 / 8$ & 61 \\
\hline 3 & & $\mathrm{O}_{2}$ & $50 / 12$ & 69 \\
\hline 4 & & $\mathrm{O}_{2}$ & $50 / 12$ & 72 \\
\hline 5 & & $\mathrm{O}_{2}$ & $50 / 12$ & 63 \\
\hline 6 & & $\mathrm{O}_{2}$ & $50 / 18$ & 70 \\
\hline 7 & & $\mathrm{O}_{2}$ & $50 / 18$ & 73 \\
\hline
\end{tabular}

${ }^{a}$ All of the reactions have been performed in the presence of $\mathrm{PdCl}_{2}\left(\mathrm{CH}_{3} \mathrm{CN}\right)_{2} \quad 10 \%$ and THF as a solvent. ${ }^{b}$ Yields refer to isolated products. (entry 2, Table 3) was smoothly obtained after $8 \mathrm{~h}$ at $50{ }^{\circ} \mathrm{C}$ in a $61 \%$ yield, while $p-\mathrm{MeOC}_{6} \mathrm{H}_{4} \mathbf{4 d}$, thienyl $\mathbf{4 e}$, and $p$-bromophenyl $4 \mathbf{f}$ derivatives required longer reaction times.

Phenyl derivative $\mathbf{2} \mathbf{b}$ proved to be the hardest substrate to cyclize into $4 \mathbf{b}$; however, in this case, the reaction time also remained reasonable ( 24 h, entry 1 , Table 3 ). Remarkably, tetrasubstituted pyrroles $\mathbf{4 h}$ and $\mathbf{4} \mathbf{j}$ were efficiently obtained under optimized and mild conditions.

In summary, a new and simple method for the synthesis of tri- and tetrasubstituted $N$-tosylpyrroles has been described. The use of $N$-tosylalkoxydienylamines as a starting material is particularly convenient and innovative for the rapid generation of pharmaceutically interesting pyrroles rapidly and with high diversity. Moreover, the cyclization reaction relies on an aminopalladation process under a dioxygen atmosphere, which has so far rarely been described on dienes in the literature.

Acknowledgment. We gratefully thank the Italian MIUR and Regione Piemonte (BioBits project, CIPE 2007) for financial support.

Supporting Information Available: Typical experimental procedures and spectroscopic and analytical data for compounds $\mathbf{2 a}-\mathbf{f}, \mathbf{h}, \mathbf{j}, \mathbf{3 a}-\mathbf{f}, \mathbf{h}, \mathbf{j}$, and $\mathbf{4 b}-\mathbf{f}, \mathbf{h}, \mathbf{j}$. This material is available free of charge via the Internet at http://pubs.acs.org.

OL9015018 